\section{C OCCUPATIONAL HEALTH SOUTHERN AFRICA: A JOURNAL FOR THE REGION AND BEYOND}

G Nelson. School of Public Health, University of the Witwatersrand, Johannesburg, South Africa

\subsection{6/oemed-2018-ICOHabstracts.857}

Introduction Occupational Health Southern Africa is the only occupational health journal in southern Africa. It is published bi-monthly and its purpose is to keep occupational health practitioners(doctors, nurses, hygienists and others) informed about current local research, views of experts, and developments in occupational health (including occupational medicine and occupational hygiene), and to provide a publishing platform for both novice and experienced researchers in the region.

Methods The issues of the Journal from 2012 to 2017 were perused $(n=36)$. The countries of origin of the first and contributing authors were reviewed, and the experience of the first authors was classified as 'student' or 'established' researcher. Papers that had been rejected in the 6 year period were also analysed, using the same metrics.

Results The majority of papers published were by authors from South Africa; less than 5\% were by authors outside of that country. Less than $1 \%$ of published papers were by authors outside of Africa. The proportions of papers published by novice and established authors were similar. Most of the rejected papers were by novice authors or by those outside South Africa.

Discussion Papers published in Occupational Health Southern Africa by authors from southern African countries other than South Africa are greatly underrepresented. There is a need to more widely publicise the Journal and encourage young researchers from the region to submit papers. This local journal is the ideal platform for students and novice researchers to disseminate their research results.

\section{3d STATUS OF REGULATIONS ON HEALTH AND SAFETY IN MINING IN KENYA SINCE ENACTMENT OF THE OCCUPATIONAL HEALTH AND SAFETY ACT, 2007}

WR Makokha. Kenyatta University, Nairobi, Kenya

\subsection{6/oemed-2018-ICOHabstracts.858}

Introduction Large and small scale mining in Kenya has been in practice for 100 years. This includes mining of minerals like soda ash, gold, flourspar, gemstones, quarrying. As an occupation with varied risks, regulations have been used to ensure the health, safety and welfare of workers. There have been various regulations governing some aspects of mining including health and safety. Such laws included Mining Act CAP 306 and 1951 for the Factories Act CAP 514 whose purpose was to make provision for health, safety and welfare of persons employed in factories and other places.

Methods A systematic review was conducted after setting the research questions. Online databases and sources were identified to conduct the review. The articles under review were limited to provisions on health and safety in mining laws. Online sources used included law reports database, Extractives Baraza, Ministry of Labour and Ministry of Mining Website.

Results Health and safety Laws and Regulations in mines were repealed on enactment of the Occupational Health and Safety Act, 2007. The current Mining Act of 2016 recognises small scale mining as a legal mining activity. However, there are no specific regulations on the health and safety provisions for this group of workers. Kenya has not ratified a number of International Labour Organisation (ILO) conventions on health and safety.

Conclusion Kenya has taken notable steps in ensuring mining industry has regulations that govern its operations. Having artisanal and small scale mines recognised as a legal activity are indicative of these steps among others. The findings also indicate the need to have rules that are specific to the industry.

\section{OSH IN ASIA: STATE OF THE ART AND FUTURE CHALLENGES}

${ }^{1}$ Nguyen Bich Diep*, ${ }^{2}$ Shyam Pingle. 'National Institute of Occupational and Environmental Health, Hanoi, Vietnam; ${ }^{2}$ Indian Institute of Public Health Gandhinagar, Gandhinagar, Gujarat, India

\subsection{6/oemed-2018-ICOHabstracts.859}

Aim of special session This Special Session dedicate to Asia region to allow representatives from different Asian countries to present the results achieved in improving occupational health and safety in their country as well as to discuss about emerging issues or challenges in the coming time. This session will expect to include 4-6 speakers from Asian Countries that will present their experiences in implementing occupational health at national/regional level.

Nguyen Bich Diep ${ }^{1 *}$, Sunil Kumar JOSHI ${ }^{2}$, Junming Dai ${ }^{3}$, Zhijun ZHOU $^{3}$, R.Rajesh ${ }^{4}$, Toru YOSHIKAWA ${ }^{5}$, Muchtaruddin MANSYUR $^{6}$

${ }^{1}$ National Institute of Occupational and Environmental Health, Hanoi, Vietnam

${ }^{2}$ Kathmandu Medical College, Kathmandu, Nepal

${ }^{3}$ School of public health, Fudan University, Shanghai, China

${ }^{4}$ Group Medical Advisor, Reliance Industries Ltd., Mumbai, India

${ }^{5}$ National Institute of Occupational Safety and Health, Kawasaki, Japan

${ }^{6}$ University of Indonesia, Jakarta, Indonesia

\section{7a BETTER HEALTH CARE FOR WORKERS IN VIETNAM}

Nguyen Bich Diep. National Institute of Occupational and Environmental Health, Vietnam

\subsection{6/oemed-2018-ICOHabstracts.860}

Vietnam is a developing country in Southeast Asia and the population is 91.7 million in 2015, of which 54 million people are working age, accounting for $58.8 \%$. In 2015, the Law on Occupational Safety and Health (OSH) was promulgated and went into effect from July 1, 2016. This legislative document is a legal basis for implementing better health care for workers in Vietnam. This paper reviewed achievements of better health care activities and challenges faced while implementing this OSH law

The health care system for workers has been well organised and coordinated by the health sector from the central to local levels. The legislative documents are almost completed to cover all health care activities for workers both in formal and informal sectors. There are several activities have been done to ensure better health care for workers. The working 